\%

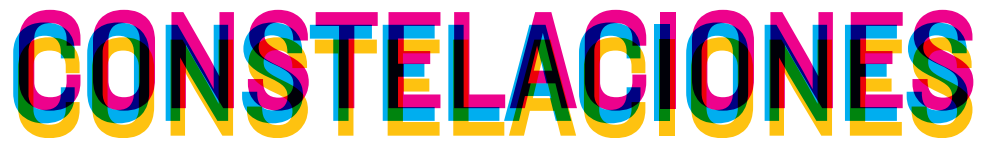

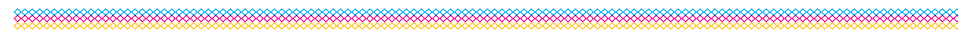


CONSTELACIONES n॰4, mayo 2016

Revista de Arquitectura de la Universidad CEU San Pablo

Architecture Magazine of CEU San Pablo University

Periodicidad anual

Annual periodicity

COMITÉ DE REDACCIÓN EDITORIAL COMMITTEE

Dirección Direction

Juan García Millán

Santiago de Molina

Jefa de Redacción Editor in Chief

Covadonga Lorenzo Cueva

Secretario de Redacción Editorial Clerk

Rodrigo Núñez Carrasco

Maquetación y producción Design and production

María Fernández Hernández

Paula Salas Sánchez

Revisión de textos en inglés English Editing

Carlota Sáenz de Tejada Granados

Responsable Web Web Page Manager

María Isabel Castilla Heredia

\section{Vocales Board Members}

Federico de Isidro Gordejuela. Escuela Politécnica Superior, Universidad CEU San Pablo, Madrid

Carlos Miguel Iglesias Sanz. Escuela Politécnica Superior, Universidad CEU San Pablo, Madrid

Ma Auxiliadora Gálvez Pérez. Escuela Politécnica Superior, Universidad CEU San Pablo, Madrid

Aitor Goitia Cruz. Escuela Politécnica Superior, Universidad CEU San Pablo, Madrid

Begoña López Rodríguez. Escuela Politécnica Superior, Universidad CEU San Pablo, Madrid

\section{CONSEJO EDITORIAL EDITORIAL BOARD}

\section{Beatriz Colomina. School of Architecture, Princeton University, New Jersey}

Carmen Díez Medina. Escuela de Ingeniería y Arquitectura, Universidad de Zaragoza

María Antonia Frías Sargadoy. Escuela Técnica Superior de Arquitectura, Universidad de Navarra

Juan Miguel Hernández Léon. Escuela Técnica Superior de Arquitectura, Universidad Politécnica de Madrid Juan José Lahuerta Alsina. Escuela Técnica Superior de Arquitectura, Universidad Politécnica de Cataluña, Barcelona Eduardo Leira Sánchez. Ex director del Plan General de Ordenación Urbana, Madrid Joaquín Medina Wamburg. Facultad de Aquitectura Diseño y Urbanismo, Universidad de Buenos Aires Zaida Muxí Martínez. Escuela Técnica Superior de Arquitectura, Universidad Politécnica de Cataluña, Barcelona José Joaquín Parra Bañón. Escuela Técnica Superior de Arquitectura, Universidad de Sevilla Víctor Pérez Escolano. Escuela Técnica Superior de Arquitectura, Universidad de Sevilla Fernando Pérez Oyarzún. Escuela de Arquitectura y Diseño, Pontificia Universidad Católica, Santiago de Chile Judith Sheine. School of Architecture and Allied Arts, University of Oregon, Portland Andrés Walliser Martínez. Global Design, New York University, Nueva York

ISSN 2340-177X

Depósito legal M-13872-2013

(c) de los textos, sus autores

(c) de las imágenes autorizadas

(c) Revista Constelaciones

(c) Escuela Politécnica Superior, Universidad CEU San Pablo

Universidad CEU San Pablo

Escuela Politécnica Superior

Urbanización Montepríncipe, s/n

Alcorcón, 28925. Madrid (España)

constelaciones@eps.ceu.es

www.uspceu.es

www.revistaconstelaciones.wordpress.com

Edición Edition

Fundación Universitaria San Pablo CEU

Madrid, España

Impresión Printing

VA Impresores

Impreso en España Printed in Spain

Distribución Distribution

CEU Ediciones

Los textos que componen Constelaciones se obtienen mediante convocatoria pública. Para que los trabajos recibidos entren en el proceso de selección de los artículos a publicar deben ser trabajos originales no publicados anteriormene, con una extensión recomendada de 3.000 palabras, título, resumen (un máximo de 150 palabras) y palabras clave (un mínimo de cuatro palabras), en español y en inglés. Tras haber cumplido estos requisitos (y los correspondientes incluidos en las normas editoriales de la revista, disponibles para consulta en formato digital desde el comienzo de la convocatoria), tiene lugar un proceso de revisión y evaluación de los artículos previa aceptación de los mismos para su publicación. Para acometer dicho proceso, y con el fin de asegurar la calidad de los contenidos, la Revista Constelaciones recurre a evaluadores externos a la institución editora y anónimos (cada artículo es evaluado por dos de ellos) encargados de someter a crítica los mismos. Todos los artículos de investigación publicados en esta revista han pasado por dicho proceso. La recepción de artículos se extendió hasta el 30 de septiembre de 2015. Texts included in Constelaciones are obtained by public announcement. Only original papers that have not been previously published will be included in the process of selection of articles. They should not exceed 3.000 words and should include a title, an abstract (no more than 150 words) and keywords (a minimum of four words), in Spanish and English. After having fulfilled these requirements (and those included in magazine editorial standards, available for consultation from the beginning of the Call for Papers), occurs a process of review and evaluation of articles upon acceptance of them for publication. To undertake this process, and in order to ensure the quality of the contents, Constelaciones turns to external and anonymous evaluators to the institution (each article is evaluated by two of them) responsible for the critic. All the articles published in this journal have undergone this process. The deadline for reception was extended until September 30, 2015.

Todos los derechos reservados. Esta publicación no puede ser reproducida, ni en todo ni en parte, ni registrada, ni transmitida, ni almacenada en ninguna forma ni por ningún medio, sin la autorización previa y por escrito del equipo editorial. En este número se han utilizado algunas imágenes de las que no se ha podido identificar al propietario de los derechos. En estos casos hemos entendido que las imágenes son de libre uso. En caso de identificar alguna de estas imágenes como propia, por favor, póngase en contacto con la redacción de Constelaciones. Los criterios expuestos en los diversos artículos de la revista son responsabilidad exclusiva de sus autores y no reflejan necesariamente los que pueda tener el equipo editoral. El equipo editorial de la revista no se responsabiliza de devolver la información enviada a la redacción a no ser que se le solicite expresamente. All rights reserved. This publication cannot be reproduced, in whole or in part, nor registered, transmitted or stored in any form or by any means, without the written permission of the Editorial team. In this issue some images were used without knowing the owner of the rights. In these cases, we have understood that the images are free of use. In case you identify any of these images as your own, please, contact with the Editorial staff of Constelaciones. The opinions expressed in this issues's articles are entirely the responsibility of their authors and are not necessarily shared by the editors of this journal. The publisher don't take responsibility for returning submitted material which is not expressly requested. 


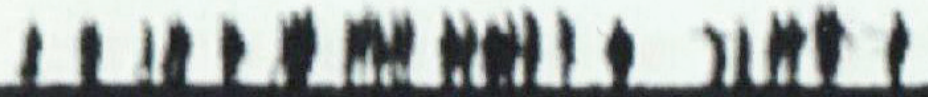

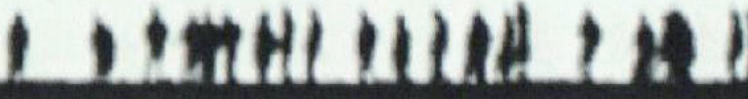

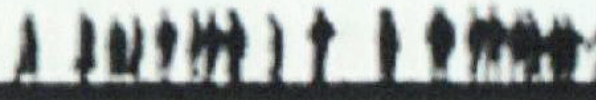

arententand

IXXHIII

II

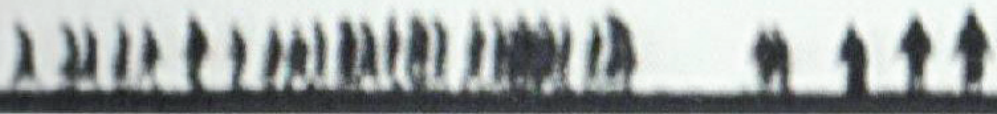

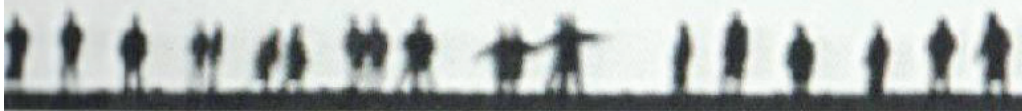

\section{- ll anti.}




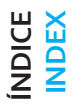
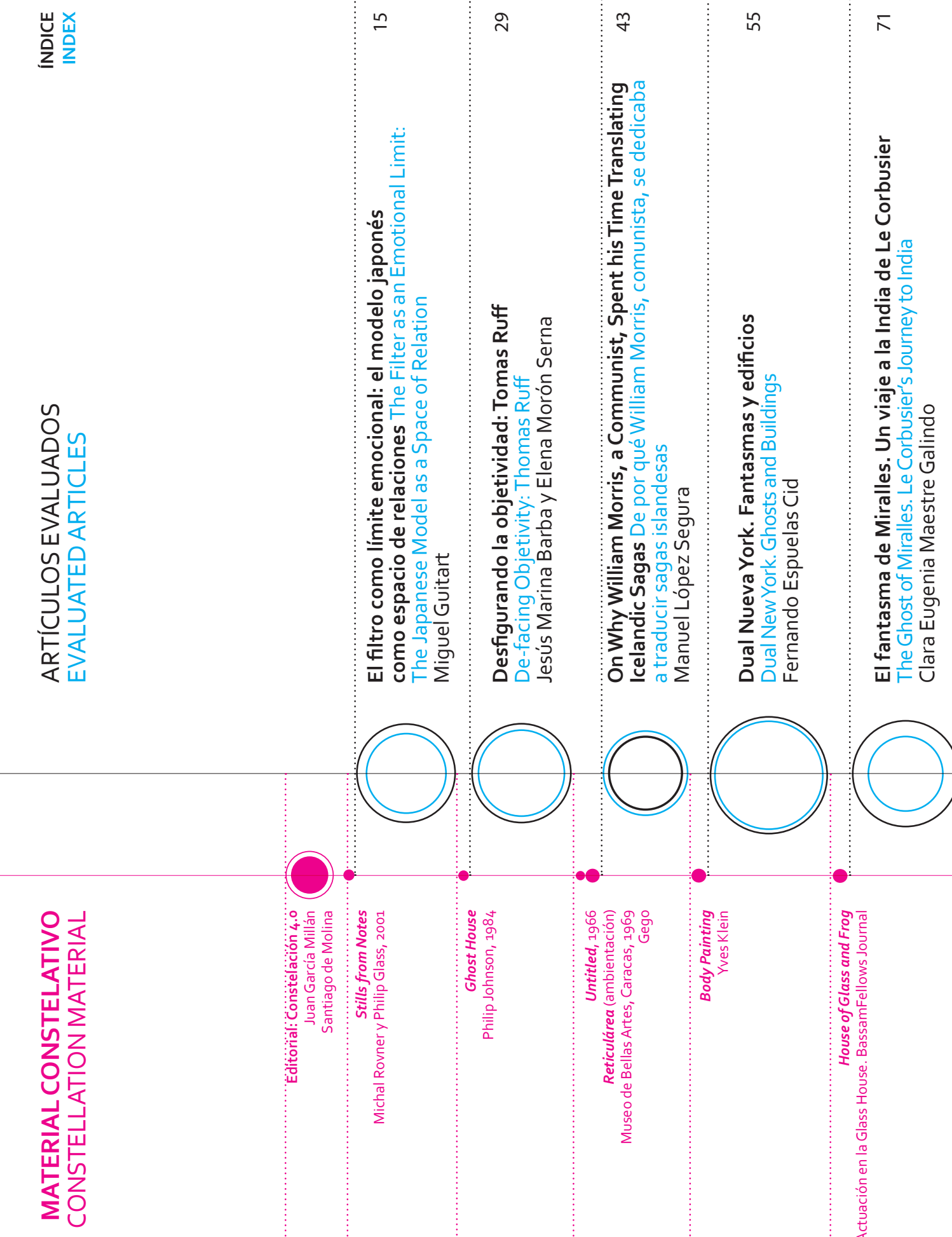

容耪
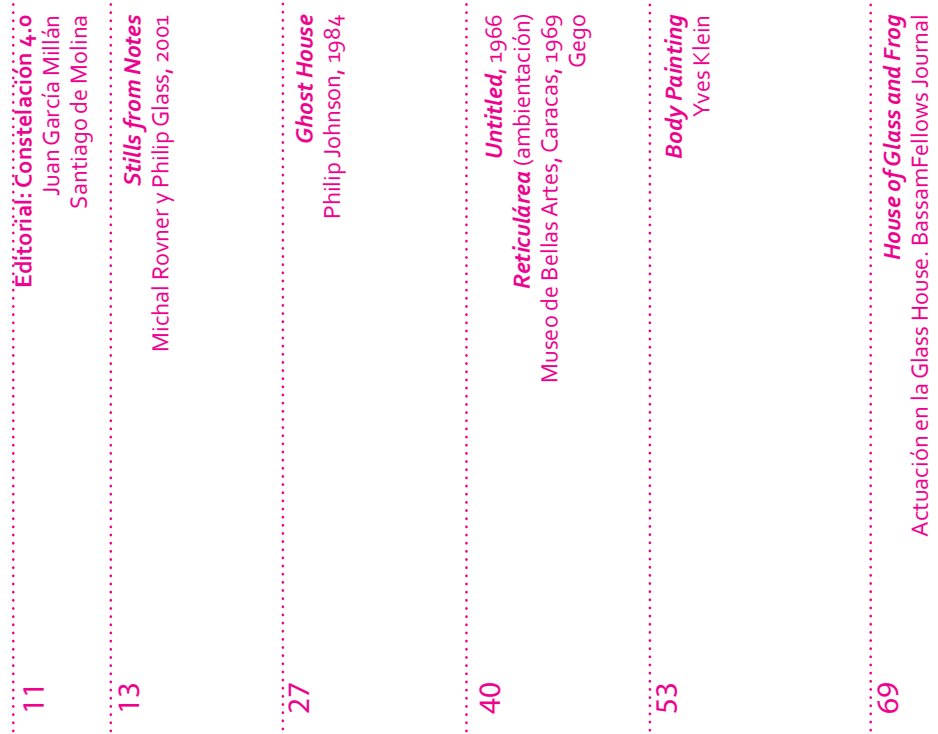


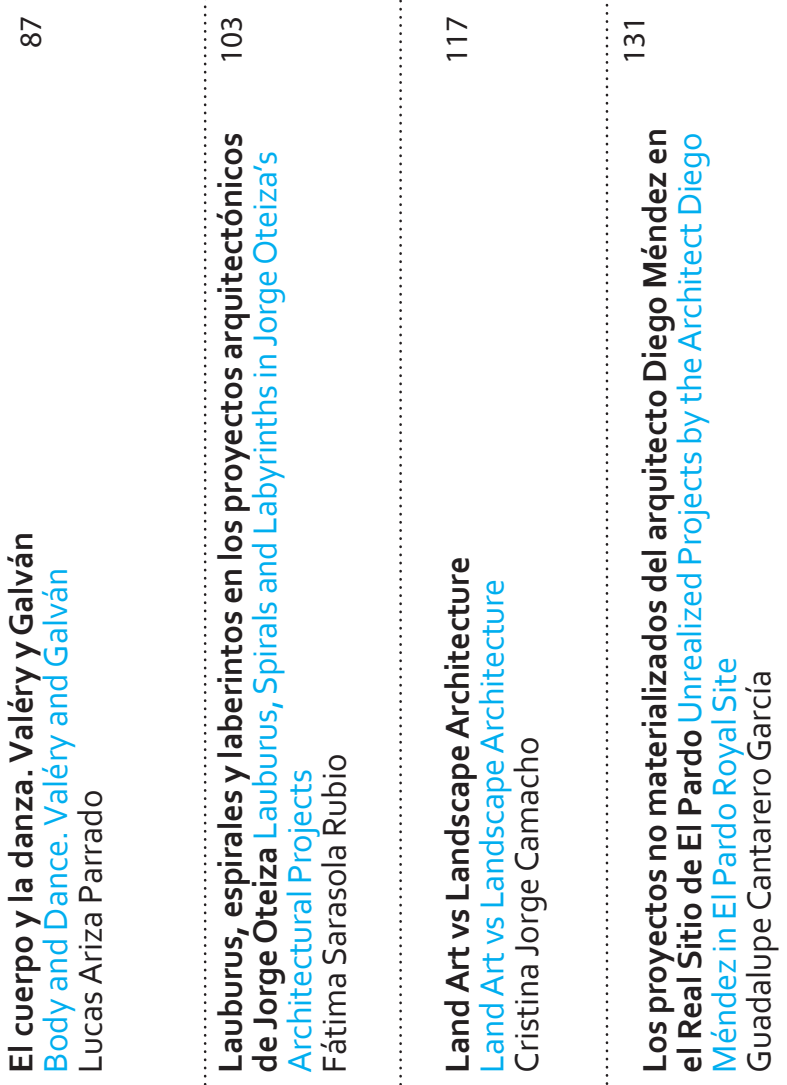




\title{
Land Art vs Landscape Architecture
}

\section{Land Art vs Landscape Architecture}

\author{
Cristina Jorge Camacho \\ Escuela de Arquitectura, Universidad de Alcalá de Henares, Madrid \\ Traducción Translation Servicio de traducción de la Universidad de Alcalá de Henares
}

\section{Palabras clave Keywords}

Meteorología, software de fluidos, Urbanismo del paisaje, Land Art, Philippe Rahm, James Corner Meteorology, Fluids software, Landscape Urbanism, Land Art, Philippe Rahm, James Corner

\section{Resumen}

La descripción de los fenómenos atmosféricos según los grados de intensidad -vientos escala Beaufort 0, 1, 2,... y su representación mediante diagramas sirven para medir futuras contribuciones energéticas y prevenir sequías e inundaciones a través de programas de simulación meteorológica como Real Flow o Flow Design en el entorno BIM. Como antecedente en el control de estos parámetros, determinados videos de obras de Land Art muestran cómo la acción del viento, la lluvia o los relámpagos potencian los efectos del tiempo sobre dichas obras como Air Art. Actualmente estas mediciones se utilizan en sistemas cerrados como las instalaciones domésticas Interior Weather de Philippe Rahm o Rain de Junya Ishigami o en sistemas abiertos como las redes de instalaciones Infraestructural Urbanism de Stan Allen o Landscape Urbanism de James Corner. La descripción de éstos diagramas, vídeos y programas informáticos tiene como objetivo integrar las fases y grados de intensidad de los parámetros meteorológicos en proyectos a cualquier escala

\section{Abstract}

The description of weather events varying degrees of intensity - Beaufort wind scale $0,1,2, \ldots-$ and their representation through diagrams are accurate ways of measuring for future energy needs and controlling drought and floods. These systems are applied in weather simulation software such as Real Flow or Flow Design for BIM. As background information about monitoring these pressure parameters, several videos of Land Art show how wind, rain and lighting are focussed on the effects of time on these works like Air Art. Nowadays, these measures are used in closed systems such as the domestic installations of Interior Weather by Philippe Rahm and Rain by Junya Ishigami, as well as in open systems such as as the network of facilities of Infrastructural Urbanism by Stan Allen or Landscape Urbanism by James Corner. The description of these diagrams, videos and software aims at supporting time phases and degrees of intensity of weather parameters on projects at all levels. 
Los edificios tienen un punto de apoyo en la tierra y varios en el aire, mientras que la tierra está cubierta por un $75 \%$ de agua y un $100 \%$ de aire. Lo sólido es variable, poco estable y depende de la erosión, mientras que lo líquido, lo meteorológico repite ciclos abiertos, en espiral. Esta inestabilidad puede controlarse desde el interior, organizando nuevos espacios que atiendan al confort ambiental y establezcan variaciones de temperatura, humedad relativa o iluminación, o bien, apropiarse de las condiciones atmosféricas del exterior y canalizarlas a través de intervenciones topográficas que conviertan partes de la ciudad en máquinas de climatización al aire libre. La primera opción funciona con redes de tuberías sin pérdidas, mientras la segunda emplea redes de terrenos porosos que modifican la temperatura ambiente, la humedad y la radiación.

\section{Metodología}

El proceso de trabajo comprende el análisis de las fases cambiantes de una instalación y los cambios de estado del territorio afectado por los fenómenos meteorológicos, mediante diagramas de flechas que indican el movimiento y a través de enlaces de vídeos que dan fluidez a la narración. Comienza la descripción de los elementos atmosféricos a través de esquemas de movilidad asociados con ciertas obras de Land Art que han utilizado estos elementos como material de proyecto. Continúa el proceso, por una parte, con aquellas instalaciones que han conseguido aislar uno de estos fenómenos en condiciones climáticas controladas simulando un laboratorio; y, por otra parte, con intervenciones a escala territorial que determinan negociaciones profesionales como el urbanismo infraestructural. Finalmente, diversos programas de simulación consiguen realizar híbridos de procesos abiertos y cerrados.

\section{Grados de intensidad de los meteoros}

Como antecedente de las infraestructuras de paisaje son seleccionadas diversas obras del movimiento Land Art que utilizan más los elementos del clima que la

Buildings have one point of contact on the ground but several in the air, while $75 \%$ of the Earth is covered by water and $100 \%$ by air. Solids are variable, unstable and subject to erosion, whereas liquids and the weather repeat open, spiralling cycles. This instability can be controlled from the interior by designing new spaces that provide environmental comfort and establish variations in temperature, relative humidity and light: alternatively, external weather conditions can be appropriated and channelled by means of topographical interventions that transform parts of a city into open air machines for controlling heating and cooling. The first option uses networks of sealed pipes, whereas the second employs networks of porous land to modify the ambient temperature, humidity and radiation.

\section{Methodology}

The working methodology encompassed an analysis of the changing phases of an installation and changes in the status of the terrain affected by meteorological phenomena using arrow diagrams to indicate motion and video links to endow fluidity to the narrative. The description of atmospheric elements commences with patterns of movement associated with certain Land Art works that have used these phenomena as material for the project. The process continues on the one hand with installations that have successfully isolated one of these phenomena in climatically controlled conditions, simulating a laboratory; and, on the other, with territorial-scale interventions that determine professional negotiations such as infrastructural urbanism. To conclude, various simulation programs have successfully created hybrids of open and closed processes. 
tierra como materia prima. Hay dos actitudes frente a los fenómenos atmosféricos: el espectador que domina y aquel que se apropia. Ante el viento, la lluvia o el trueno, uno de ellos calcula los efectos y observa desde un habitáculo que ha construido especialmente para protegerse de esos efectos; el otro permanece a la intemperie, situándose cerca de ellos. Los materiales principales son el aire, el agua y el fuego en sus diferentes estados: brisa, viento, ciclón, nubes, niebla, lluvia, nieve, granizo, relámpagos, truenos y tormentas. Artistas como Christo, Richard Long, Andy Goldsworthy, James Turrell, Walter de María o Nancy Holt emplean el clima como factor determinante y la fotografía, el video y el cine son los medios utilizados para registrar las obras: el tiempo que hace y el tiempo que dura.

Los meteoros aéreos. Los meteoros de aire comprenden la brisa, el viento y el ciclón. El estado extremo es el huracán y forma torbellinos de aire.

LA BRISA Y EL VIENTO. La brisa está compuesta por franjas homogéneas producidas por la diferencia de temperatura entre la tierra y el agua que forman un ángulo agudo con la superficie. Los vientos periódicos regulares o globales (alisios o monzones) son láminas paralelas; los vientos singulares y locales (bora, mistral, siroco, etc.) son láminas quebradas sin orden, y los vientos irregulares o variables son láminas que tienden a cerrarse. La escala de Beaufort es una medida empírica para la intensidad del viento que otorga un número y una denominación según la velocidad, el estado del mar y los efectos en tierra. (Fig. 1)

Christo explica en el video 5600 Cubicmeter Package, filmado en 1968 cómo fue el proceso de construcción de esta estructura aérea diseñada en el Massachusetts Institute of Technology (Boston) considerando la obra como un contenedor de aire, una envolvente. (Fig. 2)

EL CICLón. Es el nombre genérico de todas las perturbaciones atmosféricas de carácter giratorio y distribuye su denominación en huracán (América), ciclón (Europa), tornado (Africa) y tifón o baguio (Asia). Tres son los movimientos que determinan su forma: el movimiento de rotación, el movimiento de traslación o de impulsión este-oeste y el movimiento de nutación. (Fig. 3)
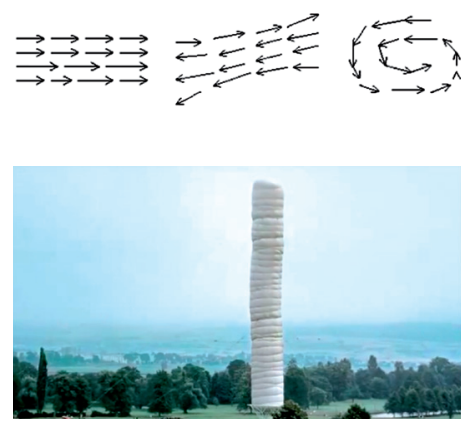

Fig. 1. Jorge, Cristina. Diagramas de viento, Flechas, vectores y fuerzas: sobre la fluidez en arquitectura, 2003.

Fig. 2. Christo: 5600 Cubicmeter Package, 1967-1968. [https://www.youtube.com/ watch?v=Tcj1QQkdRSM].

\section{Degrees of intensity of weather phenomena}

As antecedents for landscape infrastructures, various works have been selected from the Land Art movement that have used climatic elements more than the land as their raw material. There are two approaches to atmospheric phenomena: the spectator who dominates and the one who appropriates. In the presence of wind, rain or thunder, one of these calculates the effects and observes from a shelter that has been specially built to give protection from these effects; the other remains outdoors, in proximity to them. The main materials are air, water and fire, in all their different aspects: breezes, wind, cyclones, clouds, fog, rain, snow, hail, lightning, thunder and storms. Artists such as Christo, Richard Long, Andy Goldsworthy, James Turrel, Walter de María and Nancy Holt have used the weather as a decisive factor, employing photography, video and film to record their works: the weather conditions and their duration.

Air phenomena. Air phenomena include breezes, wind and cyclones. The extreme state is a hurricane, which forms whirlwinds.

BREEZES AND WIND. Breezes consist of homogeneous bands caused by the difference in temperature between land and water, and form an acute angle with the surface. Periodic or global winds (trade winds or monsoons) are parallel bands; unique and local winds (such as the Bora, Mistral or Sirocco) are chaotic, fractured bands; and irregular or variable winds (with no name) are bands that tend to close. The Beaufort scale is an empirical measure of wind speed that assigns a number and name to types of wind according to speed, sea conditions and land conditions. (Fig. 1) 
En la primera parte de un video que narra todo el proceso de construcción de Valley Curtain, Christo y Jean-Claude discuten sobre un dibujo previo cómo será el efecto del viento sobre una tela vertical colgada en el valle que retiene aire en vez de agua. (Fig. 4)

Los meteoros acuosos. Comprenden las nubes, la niebla, la bruma, el rocío, la escarcha, el sereno, la lluvia, la nieve y el granizo. El estado extremo es la inundación y forma torbellinos de agua.

LAS NUbes, LAS Nieblas y LAS bRUmas. Desde el mar asciende el vapor de agua hasta alcanzar las capas de aire frío y una vez aglomerado en nubes intercepta los rayos solares, por los cuales asciende a mayor altura mientras el vapor de agua inferior continua enfriándose cada vez más. Esta acumulación descenderá por su propio peso hacia el mar. El rocío, la escarcha y el sereno son procesos selectivos, dependen de las condiciones de los materiales sobre los cuales se depositan y no humedecen por igual como la lluvia.
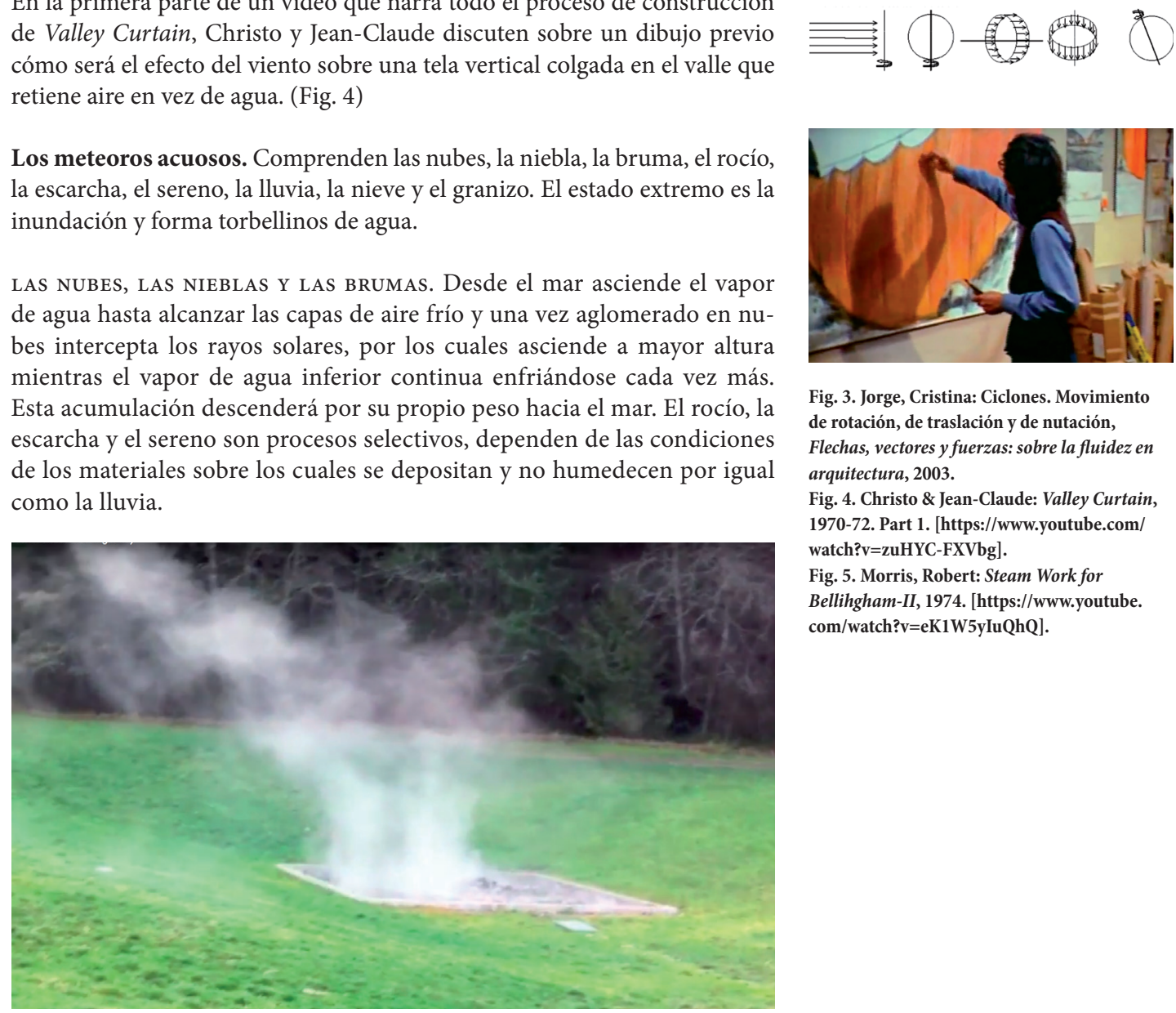

Fig. 3. Jorge, Cristina: Ciclones. Movimiento de rotación, de traslación y de nutación, Flechas, vectores y fuerzas: sobre la fluidez en arquitectura, 2003.

Fig. 4. Christo \& Jean-Claude: Valley Curtain, 1970-72. Part 1. [https://www.youtube.com/ watch? $=$ zuHYC-FXVbg].

Fig. 5. Morris, Robert: Steam Work for Bellihgham-II, 1974. [https://www.youtube. com/watch?v=eK1W5yluQhQ].

In the video 5600 Cubicmeter Package, recorded in 1968, Christo explains the process of constructing this aerial structure designed at the Massachusetts Institute of Technology (Boston), and considers the work a container of air, a wrapping. (Fig. 2)

CYCLONES. Cyclone is the generic name for all atmospheric perturbations that rotate and which may variously be called a hurricane (America), a cyclone (Europe), a tornado (Africa) and a typhoon or bagyo (Asia). The cyclone's shape is defined by three movements: rotation, displacement or east-west impulse, and nutation. (Fig. 3)

In the first part of a video narrating the entire process of constructing the Valley Curtain, over a prior drawing Christo and Jean-Claude discuss what the effect of the wind will be on a vertical curtain hung across the valley and designed to retain air rather than water. (Fig. 4)

Water phenomena. These include clouds, fog, mist, dew, frost, rain, snow and hail. The extreme state is flooding, which forms whirlpools.

CLOUDS, MIST AND FOG. Water vapour rises from the sea until it reaches layers of cold air where it accumulates in clouds and is heated by the Sun, causing it to rise even higher, while the water vapour below continues to cool. This accumulation then falls under its own weight towards the sea. Dew and frost are selective processes; they depend on the condition of the materials on which they are deposited and do not drench like the rain. 
El vapor que desprenden las piedras dentro del rectángulo situado en una superficie cóncava corresponde a una obra de Robert Morris titulada Steam Work for Bellihgham-II y forma parte de la Western Washington University Sculpture Collection. (Fig. 5)

LA LLUVIA. A diferencia del rocío, la forma de una gota de lluvia no es redonda al ser la caída una condición formal. Hay tres modelos en alzado de lluvia: caudales infinitos; después flujos por oleadas y en todos los sentidos y, en tercer lugar, corrientes inclinadas con una pendiente máxima. También existen tres escalas: las lluvias locales en medio de una atmósfera tranquila, las lluvias accidentales del encuentro de dos corrientes de aire y las lluvias generales de los grandes movimientos de la atmósfera. (Fig. 6)

El montaje de varios vídeos filmados desde un helicoptero, un coche o un barco ofrece la vista aérea de un conjunto de sombrillas y paraguas, primero de color azul sobre un valle fértil con un río y cultivos de arroz en Japón y después de color amarillo sobre un valle árido con una autovía y con problemas de sequía en la costa oeste de los Estados Unidos. (Fig. 7)

NIEVE Y GRANIZO. El sentido ordenado de los copos de nieve tiene lugar porque las moléculas del vapor de agua pasan de ser núcleos de condensación formados por sales marinas a formar minúsculas esferas líquidas de constitución hexagonal flotando en el aire. El sinsentido o el caos de las partículas de granizo produce formas rápidas cuando los movimientos son muy violentos, porque las gotas sobre fundidas solidifican bruscamente manteniendo burbujas de aire comprimido.

Andy Goldsworthy reflexiona sobre los sistemas de aislamiento térmico mostrando la pieza Snow House, una envolvente de heno atada mediante cuerdas que aísla una bola de nieve de 1,80 metros de diámetro en su interior, como un proceso opuesto al de construcción de un iglú donde el hielo actúa como material de construcción. (Fig. 8)
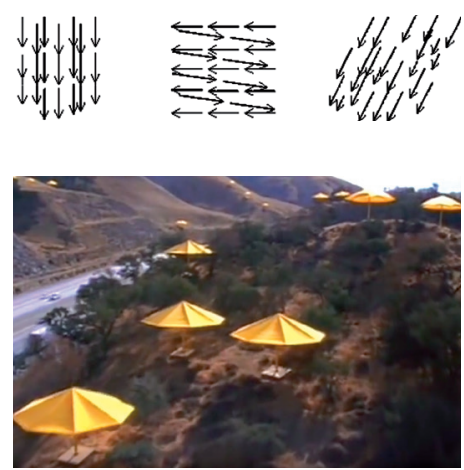

Fig. 6. Jorge, Cristina: Lluvias locales, accidentales y generales en Flechas, vectores y fuerzas: sobre la fluidez en arquitectura, 2003.

Fig. 7. Christo \& Jean-Claude: The Umbrellas Japon-USA, 1984-1991. [https://www.youtube. com/watch?v=z057rxwJXPo].

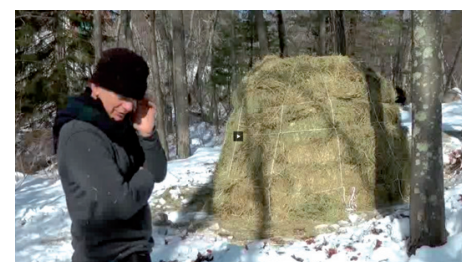

Fig. 8. Goldsworthy, Andy: Snow House, 2013. Interview, de Cordoba Sculture Park and Museum: [http://www.decordova.org/andygoldsworthy-interview].

Robert Morris's work entitled Steam Work for Bellingham-II, which forms part of the Western Washington University Sculpture Collection, consists of steam rising from stones within a rectangle sited on a concave surface. (Fig. 5)

RAIN. Unlike a dewdrop, the shape of a raindrop is not spherical since rainfall is a formal condition. There are three escalating models of rain: infinite flows, followed by flows in waves and in every direction, and thirdly, angled flows with a maximum slope. There are also three levels: local rain in the middle of calm atmospheric conditions, rain caused by the collision of two air currents and general rain resulting from massive movement in the atmosphere. (Fig. 6)

A montage of several videos recorded from a helicopter, a car and a boat provides an aerial view of parasols, first blue in a fertile river valley with rice crops in Japan, and then yellow in a barren, drought-stricken valley with a dual carriageway on the west coast of the United States. (Fig. 7)

SNOW AND HAIL. The orderly pattern of snowflakes occurs because water vapour molecules are transformed from condensation nuclei composed of sea salts into tiny, hexagonal spheres of liquid floating in the air. The disorder or chaos of hail particles produces rapid forms when movements are extreme, because droplets on aerosols abruptly solidify, retaining bubbles of compressed air. 

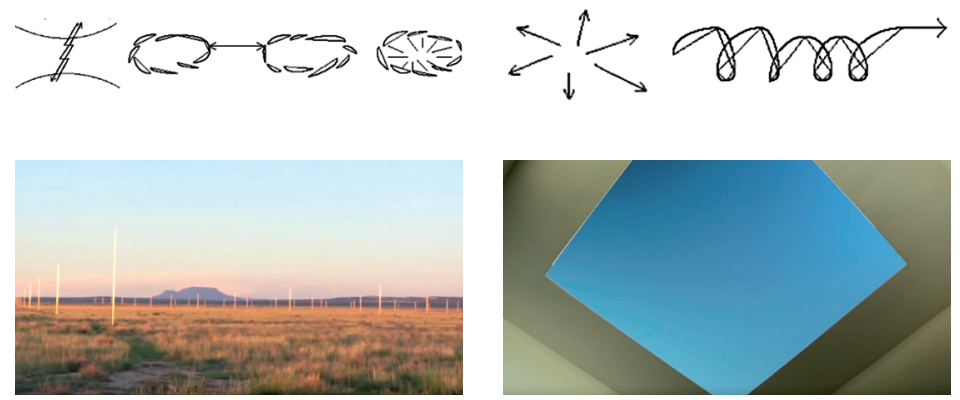

Los meteoros electromagnéticos. Los meteoros de fuego comprenden el rayo, el relámpago y el trueno y los luminosos como el halo solar, halo lunar y el arco iris. El estado extremo es el incendio y forma torbellinos de fuego.

el Relámpago. Es la manifestación luminosa del rayo y afecta a cada una de las líneas, generalmente rectas, que parten de un punto origen donde se produce una descarga de energía y señalan la dirección en que ésta es transmitida. Se produce entre la nube y la tierra, cuando los dos fluidos van uno hacia el otro, entre dos nubes electrizadas, una positiva y otra negativa y también dentro de los límites de una nube. (Fig. 9)

Eran las 6:30 del 24 de agosto de 2011 cuando filmaron un video en el emplazamiento de Lighting Field que Walter de María construyó en 1977. La cámara hace un barrido de los cuatrocientos postes metálicos separados unos de otros 61 metros en un cuadrado de 1 kilómetro de lado. (Fig. 10)

EL TRUENO. Es el sonido del rayo y se origina por la súbita dilatación e inmediata condensación del aire en todo el trayecto que recorre la chispa propagándose por ondas sonoras. El sonido puede ser ronco si el trueno resultante está formado por un ruido estrepitoso de intensidad variable o bien puede ser un sonido sordo si está compuesto por una sucesión de ruidos graves y prolongados. (Fig. 11)
Fig. 9. Jorge, Cristina: Relámpagos entre nube y tierra, entre nubes y dentro de una nube, Flechas, vectores y fuerzas: sobre la fluidez en arquitectura, 2003.

Fig. 10. De María, Walter: Lighting

Filed, 1970. [https://www.youtube.com/ watch?v=umwWKPcPINU].

Fig. 11. Jorge, Cristina: El trueno ronco y el trueno sordo, Flechas, vectores y fuerzas: sobre la fluidez en arquitectura, 2003.

Fig. 12. Turrel, James: Meeting (Skyspace), 1980. ART21 'Exclusive'. [https://www.youtube. com/watch?v=_BuJpDXkMz8].
Fig. 13. Holt, Nancy: Sun Tunnels, 1973-1976. [https://www.youtube.com/ watch?v=6koPeWqrYho].

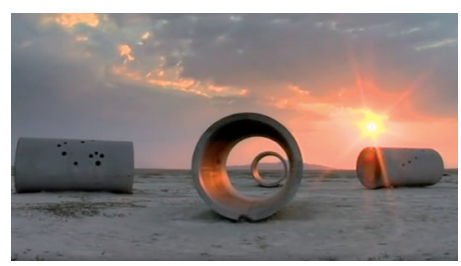

Electromagnetic phenomena. Fire phenomena include lightning, thunder, and optical phenomena such as lunar halos, solar halos and rainbows. The extreme state is fire, which forms fire whirls.

LIGHTNING. This is the luminous manifestation of usually straight bolts which are emitted from a point source where energy is discharged and depict the direction in which this energy is transmitted. Lightning is produced between the water condensation in the cloud and the subterranean water when the two fluids move towards each other, between two electrically charged clouds when one is positive and the other negative, and also within one cloud. (Fig. 9)

At 6:30 on the 24th of August, 2011, a video was recorded on the site of the Lighting Field, a work created by Walter de María in 1977. The camera pans across the four hundred metallic posts set 61 metres apart in a one kilometre long rectangle. (Fig. 10)

THUNDER. Thunder is the sound of lightning and is caused by a sudden expansion and immediate contraction of air along the length of the bolt, spread by sound waves. The sound may be a loud crack if the resulting thunder is formed by a crashing noise of variable intensity, or may be a low rumble if composed of a succession of deep, prolonged noises. (Fig. 11)

James Turrell employs the material value of light as if it were gold, wood or stone, and has built a room where people feel as if they were at the bottom of an ocean of air perceiving the changes from day to night, transitions which are created through the use of metamerism, sound and time-lapse video. (Fig. 12) 
James Turrell comenta el valor material de la luz como si fuera oro, madera o piedra y construye una habitación donde las personas se sienten en el fondo de un océano de aire, percibiendo los cambios del día a la noche y estas transiciones las muestra aplicando metamerismo, sonido y timelapse en el video. (Fig. 12)

Los meteoros ópticos. Los meteoros ópticos comprenden el halo solar, el halo lunar y el arco iris.

EL HALO SOlAR, EL HALO LUNAR Y EL ARCO IRIS. Son círculos luminosos formados en las regiones más frías de ambos hemisferios y tienen como eje el sol o la luna. Cuando los astros se encuentran muy cerca del horizonte, se forman en el diámetro horizontal unas manchas brillantes: parhelios o soles falsos si el astro es el sol y paraselenes o lunas falsas si es la luna. El arco iris, formado por varios arcos luminosos que se apoyan en el horizonte, no tiene como eje ningún astro.

Sun Tunnels, de Nancy Holt (1977) está formado por cuatro tubos de hormigón armado de 2,75 metros de diámetro colocados horizontalmente en el desierto de Utah con una configuración en aspa. Dentro de los tubos, unos óculos horadados representan las constelaciones y al final de uno de los tubos hay un vidrio moldeado que provoca la difracción de la luz del sol al atardecer. (Fig. 13)

Los meteoros globales. Son meteoros que engloban todos los demás y están representados por las tempestades.

LA TEMPESTAD. Es una fuerte perturbación donde las nubes poco a poco van tomando densidad y ocupan el cielo, los torbellinos de polvo se levantan y el viento adquiere cada vez mayor velocidad. A estas rachas de viento le siguen gruesas gotas de lluvia, no tardando en verse los resplandores de los relámpagos y los truenos. Pueden ser tormentas locales producidas por el movimiento de rotación o tormentas globales resultado de las interferencias de dos movimientos: rotación y traslación. (Fig. 14)
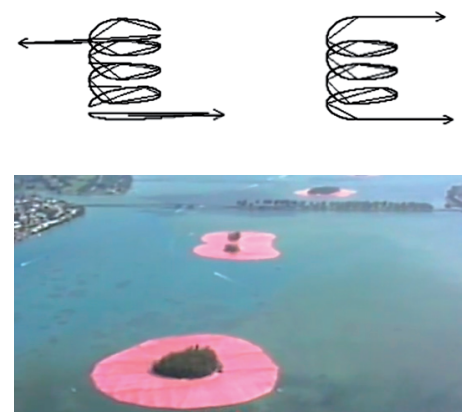

Fig. 14. Jorge, Cristina: Tormentas locales y globales, Flechas, vectores y fuerzas: sobre la fluidez en arquitectura, 2003.

Fig. 15. Christo \& Jean-Claude: Surrounded

Islands, 1980-1983. A Nurturing Gaze. [https:// www.youtube.com/watch?v=QUSFXdqyndg].

Optical phenomena. Optical phenomena include lunar halos, solar halos and rainbows.

LUNAR HALOS, SOLAR HALOS AND RAINBows. These are bright circles around the Sun or moon that can be seen in the colder regions of both hemispheres. When the Sun or moon is very close to the horizon, bright spots may appear on the horizontal side of their diameter: parhelia or sun dogs in the case of the Sun and paraselenae or moon dogs in the case of the moon. Rainbows consist of multicoloured arcs that appear to rest on the horizon, and do not form around a celestial body.

Sun Tunnels by Nancy Holt (1977) consists of four reinforced concrete tubes measuring $2.75 \mathrm{~m}$ in diameter that have been laid horizontally in the Utah desert in the shape of an X. Inside the tubes, small holes have been drilled to represent constellations, and one of the tubes has moulded glass at the end which causes the light of the Sun to diffract at sunset. (Fig. 13)

Global phenomena. Global phenomena encompass all others and are represented by storms.

STORMS. These are strong disturbances where clouds gradually densify and occupy the sky, whirlwinds of dust rise and the wind becomes increasingly stronger. These gusts of wind are followed by heavy drops of rain, and shortly after by flashes of lightning and thunder. Storms can be local, produced by the movement of rotation, or global, the result of the collision of two movements: rotation and displacement. (Fig. 14) 
Las imágenes capturadas por reporteros que trabajaban para WTV-4 en Miami en mayo de 1983 giran alrededor de las once islas situadas en Biscayme Bay que suman en total 6,5 millones de metros cuadrados de telas horizontales que flotan completamente sobre la superficie del mar absorbiendo todos sus movimientos. (Fig. 15)

\section{Climatología interior dominada}

Respecto al control del clima que existe en el lado interno de la ventana, surgen nuevas configuraciones de los espacios interiores que van más allá de las particiones físicas y definen áreas de actividad a través de cambios que afectan a los sentidos.

En el texto 'Form and Function Follow Climate' (2006), Phillipe Rahm busca los vínculos originales que la arquitectura primitiva tenía con el clima. En el proyecto Interior Weather construye un laboratorio formado por dos habitaciones conectadas para proyectar una arquitectura con usos por la confluencia de tres parámetros: temperatura, humedad relativa e iluminación $(\mathrm{T} x$ lux $x \mathrm{HR}=$ forma y función). La primera habitación es una micro-geografía, donde los datos meteorológicos fluctúan en tiempo real. Después, los sensores distribuidos por las seis superficies miden las variaciones de los tres parámetros y los envían a la segunda habitación. (1) (Fig. 16)
Fig. 16. Rahm, Philippe; Interior Weather, 2006. [https://vimeo.com/18696539]

Fig. 17. Ishigami, Junya: Rain. Architecture as Air: Study for Château la Coste.

Architecture Biennale, Venice 2010. [https:// www.youtube.com/watch?v=27smHwT4uFU]
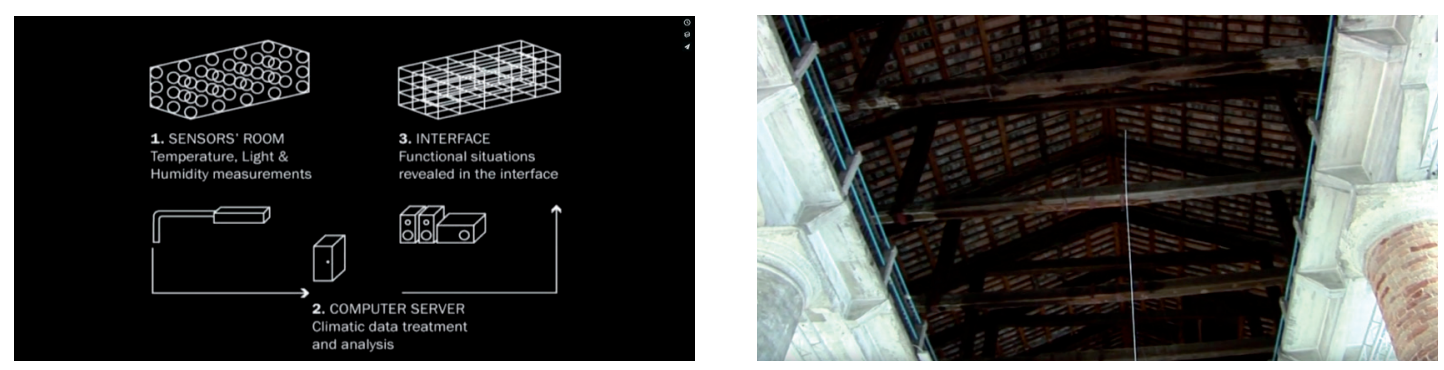

The images captured by reporters working for WTV-4 in Miami in May 1983 revolved around the eleven islands sited in Biscayne Bay, which consisted of a total of 6.5 million square metres of horizontal fabric floating on the surface of the sea, absorbing all its movement.

\section{Dominating the indoor climate}

Regarding climate control on the inner side of a window, new configurations of interior spaces have emerged that go beyond physical partitions to define areas of activity by means of changes that affect the senses.

In the text 'Form and Function Follow Climate' (2006), Phillipe Rahm seeks the original links that early architecture had with climate. In the "Indoor Weather" project, he built a laboratory consisting of two connected rooms, to create an architecture with applications according to the confluence of three parameters: temperature, relative humidity and lighting $(\mathrm{T} x \mathrm{x}$ lux $\mathrm{x} \mathrm{RH}=\mathrm{form}$ and function). The first room is a microgeographic space where meteorological data fluctuate in real time. Then, the sensors installed on the six surfaces measure variations in the three parameters and send them to the second room. (1) (Fig. 16)

In line with the previous text is 'Rain', written by Junya Ishigami, in which the Japanese architect reflects on the scale of atmospheric phenomena, which he considers extremely small in relation to the normal scale of architecture. In archi- 
En sintonía con el texto anterior aparece el escrito 'Rain' de Junya Ishigami, donde el arquitecto japonés reflexiona sobre la escala de los fenómenos atmosféricos, la cual considera extremadamente pequeña en relación con la escala normal de la arquitectura. En arquitectura, cuando el edificio está formado por la acumulación de elementos diminutos y etéreos, los límites entre espacio y estructura tienden a borrarse, como el vapor de agua condensado en el aire que forma nubes y causa la lluvia al caer. Es posible imaginar edificios formados por una mayor densidad de partículas y emplear para este propósito nuevos materiales procedentes de la nanotecnología. (2) (Fig. 17)

\section{Meteorología exterior apropiada}

Respecto al aprovechamiento de los fenómenos meteorológicos que se encuentran en el lado externo de la ventana aparecen nuevas estrategias topográficas, de caudal o de control solar que emplean la meteorología como si fuera una máquina de acondicionamiento de espacios exteriores. (3)

Como inicio de nuevas proyecciones territoriales, el texto 'Urbanismo infraestructural' (1999), de Stan Allen centra la atención en tres temas: territorio, comunicación y velocidad. Allen enuncia siete propuestas sobre el término infraestructura: funciona no tanto para poner determinados edificios en un emplazamiento como para construir el propio emplazamiento; evoluciona en un campo abierto de solicitaciones; habla de enunciados colectivos con múltiples autores; se acomoda a las contingencias locales manteniendo una continuidad general; dirige sistemas de flujo aunque es estática y jerárquica en forma de árbol; modifica la habitabilidad en función de las condiciones ambientales, y finalmente, permite un diseño de estructuras repetitivas. (4) (Fig. 18)

A lo largo del texto 'Terra Fluxus', James Corner habla de cómo el paisaje se comprime y concentra linealmente hasta llegar a convertirse en parte de las instalaciones al aire libre dentro de la ciudad, como el sistema de canalizaciones de agua de tormenta bajo los Back Bay Fens de Boston, los pasillos verdes

tecture, when a building is formed by the accumulation of tiny, ethereal elements, the boundaries between space and structure tend to disappear, like water vapour condensed in the air that forms clouds and causes rain to fall. It is possible to imagine buildings consisting of a higher density of particles and to use new nanotechnology materials for this purpose. (2) (Fig. 17)

\section{Appropriating outdoor weather}

With respect to the use of meteorological phenomena that occur outside a window, new strategies have emerged that use topography, flow or solar control, employing the weather as if it were a machine to control the climate of exterior spaces. (3)

As a starting point for new territorial projections, the text 'Infrastructural Urbanism' (1999) by Stan Allen focuses on three subjects: territory, communication and speed. Allen sets out seven propositions in relation to infrastructure: it is not so much about putting buildings on a site but about constructing the site itself; it changes in an open field of requests; it is a collective statement with multiple authors; it accommodates to local contingencies while maintaining general continuity; it directs flow systems although it is static and hierarchical in the shape of a tree; it modifies habitability in accordance with environmental conditions; and lastly, it allows the design of repetitive structures. (4) (Fig. 18) 

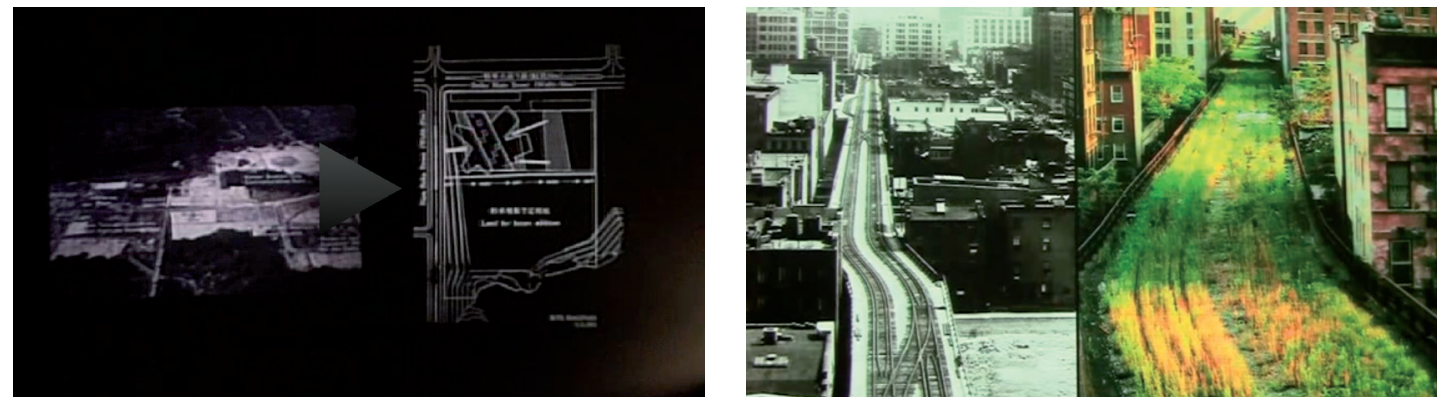

que se filtran por Stuttgart y llevan el aire fresco de las montañas a la ciudad, o bien, el río canalizado que desde las montañas de Santa Susana llega a la ciudad de Los Ángeles. (5) En su definición de 'Landscape Urbanism' define cuatro temas: los procesos a lo largo del tiempo, la organización de superficies, los métodos de funcionamiento y lo imaginario. También incluye el diagrama de circulación viaria que Louis Kahn realizó en 1953. (6) (Fig. 19)

Fig. 18. Allen, Stan: Infrastructural Urbanism, 1999. SCI-Arc Media Archive: Stan Allenclip_2845 [http://sma.sciarc.edu/subclip/stanallen-clip_2845/]

Fig. 19. Corner, James: Terra Fluxus, 2006. James Corner, ASLA. Recent Work: [https://www. youtube.com/watch?v=wcrdo4xMKD4]

\section{Programación que hibrida los parámetros interiores y exteriores}

En primer lugar, dentro de la construcción denominada lean (7) o construcción sin pérdidas, las instalaciones se apoyan en procesos termodinámicos y tienden a ser híbridas, es decir a mezclar aire acondicionado y ventilación cruzada. Dentro de este proceso, diseñado inicialmente por Toyota mediante sistemas de mejora continua y control del tiempo empleado en cada operación, es importante destacar el valor concedido al mantenimiento y adaptación de las obras.

Como segunda aproximación, esta situación mixta en el sector industrial da lugar a la generación distribuida o descentralizada (8) donde la optimización de un sistema energético híbrido tiene que dar servicio a máquinas,

Throughout the text 'Terra Fluxus', James Corner discusses how the landscape is linearly compressed and condensed until becoming part of the open air installations of a city, for example the system of storm water pipes beneath the Back Bay Fens in Boston, the green corridors that wend through Stuttgart and bring fresh air from the mountains to the city, and the channelled river from the Santa Susana mountains that flows into the city of Los Angeles. (5) In his definition of Landscape Urbanism, he defines four themes: processes over time, the organisation of surfaces, operational methods and the imaginary. He also includes Louis Kahn's 1953 diagram of road traffic. (6) (Fig. 19)

Firstly, within what is known as lean construction (7), or construction without waste, installations are based on thermodynamic processes and tend to be hybrids, combining cross-ventilation and air conditioning. Within this process, initially designed by Toyota using systems for continuous improvement and control of time spent on each operation, it is important to highlight the value accorded to maintenance and adaptation of the works.

As a second approach, this mixed situation in the industrial sector gives rise to distributed or decentralised generation, (8) where optimisation of a hybrid energy system must service machines, control fluids and manage thermal processes, while also designing energy generation and storage with limited values. This micro-generation consists of small electrical sources distributed throughout the territory to achieve a more balanced system.

In third and final place, the coordination of geometric, structural and energy parameters can be managed through the use 
manejar fluidos y gestionar procesos térmicos, al tiempo que se diseñan con valores limitados de almacenamiento y generación de energía. Esta micro generación consiste en pequeñas fuentes eléctricas distribuidas por todo el territorio que consiguen un sistema más equilibrado.

Finalmente, en tercer lugar, la coordinación de parámetros geométricos, estructurales y energéticos puede gestionarse mediante el empleo de programas como Real Flow o Flow Design en el entorno BIM (Building Information Modelling) (9) que toman los avances en computación algorítmica y las tecnologías de comunicación y los aplica en la realización práctica de redes y patrones geométricos. Es un sistema que trabaja en red: entre los espacios generados por las relaciones entre las formas; entre las disciplinas que colaboran en un proyecto y entre los grupos que materializan el proyecto.

\section{Conclusiones}

La narración de los procesos que combinan varios fenómenos atmosféricos (brisa, viento, lluvia, nieve, etc.) se apoya en las simulaciones meteorológicas, en la filmación de vídeos y en diagramas que representan los grados de intensidad y sirven para saber dónde termina la abstracción de un programa y donde comienza la empatía con un medio fluido. Esta conexión puede ser testada mediante sistemas informáticos que unifican el acondicionamiento de aire controlado con el aprovechamiento de las infraestructuras exteriores para mejorar las condiciones de los espacios abiertos, línea que ya anticiparon los artistas del movimiento Land Art al potenciar el uso de elementos climáticos en sus intervenciones. Junto a estos sistemas que trabajan en red mediante entornos BIM, se sitúa, por un lado, la construcción denominada lean o sin pérdidas que actúa mediante híbridos acondicionados con sistemas de mejora continua y control del tiempo, y por otro lado la generación descentralizada, con pequeñas fuentes de generación eléctrica distribuidas por todo el territorio. Estos procesos se apoyan en sistemas perceptivos centrados en la movilidad de los seres vivos, las instalaciones y el clima.

of programs such as Real Flow or Flow Design in the BIM (Building Information Modelling), (9) which apply advances in algorithmic computation and communication technologies to create geometric networks and patterns. The system works as a network: between the spaces generated by the relationships between shapes; between the disciplines that collaborate in a project; and between the groups that carry out the project.

\section{Conclusions}

A narrative of the processes that combine various atmospheric phenomena (breezes, wind, rain, snow, etc.) is based on meteorological simulations, recording videos, and diagrams that represent degrees of intensity and serve to indicate where the abstraction of a programme ends and empathy with a fluid medium begins. This connection can be tested by means of computer systems that combine controlled air conditioning with the use of external infrastructures to improve the condition of open spaces, an approach that was anticipated by Land Art movement artists when they began to employ climatic elements in their works. These systems that function in a network through BIM environments are combined, on the one hand, with lean or waste-free construction that operates with hybrids optimised through systems for continuous improvement and time control, and on the other, with decentralised generation using small electricity generation sources distributed throughout the territory. These processes are based on perceptive systems focusing on the mobility of human beings, installations and climate. 


\section{NOTAS}

1. RAHM, Philippe. 'Form and Function Follow Climate', en: CLÉMENT, Gilles; RAHM, Philippe. Environ (ne) ment. Milán: Canadian Centre for Architecture, Skira Editions, 2006. pp. 152-159.

2. ISHIGAMI, Junya. 'Rain', en: Another Scale of Architecture. Tokio: Seigensha Art Publising, 2010. pp. 183-212.

3. Prácticamente todas las definiciones de los meteoros aéreos, acuáticos, eléctricos y ópticos pertenecen a esta enciclopedia que analiza los fenómenos atmosféricos desde la perspectiva del intercambio de fluidos y destaca la amplitud de información que recoge cada uno de ellos. Diccionario Enciclopédico Hispano-americano de Literatura, Ciencias, Artes, etc. W.M. Jackson (ed.). Londres: Waterloo Place 14, finales del s. XIX. 4. ALLEN, Stan. 'Infrastructural Urbanism', en: Points and lines: Diagrams and Projects for the City. Nueva York: Princeton Architectural Press, 1999. pp. 46-57.

5. CORNER, James. 'Terra Fluxus', en: WALDHEIM, Charles (ed.). The landscape Urbanism Reader. Nueva York: Princeton Architectural Press, 2006. pp. 21-32.

6. "Las vías rápidas son como ríos. Estos ríos delimitan la zona a la que dan servicio, Los ríos tienen puertos. Los puertos son las torres municipales de aparcamiento; desde los puertos se ramifica un sistema de canales que da servicio al interior; desde los canales se ramifican unas dársenas sin salida. Las dársenas sirven de vestíbulo a las torres de los edificios". KAHN, Louis I. 'Toward a Plan for Midtown Philadelphia', en: Perspecta 2. 1953. Citado en CORNER, James. 'Terra Fluxus' Opus cit. 7. “En otras palabras, 'pull' versus 'push', donde 'pull' es simplemente proporcionar un producto o servicio solamente cuando es reclamado por el consumidor y donde 'push' significa fabricar un producto y después venderlo a un consumidor". MATSUNAMA, Katashi. 'Toward the Realization of ZEBs', en: Sustainable Architecture in Japan. The Continuous Challenge 1900-2010 \& Beyond. Tokio: Editorial Board Members of Nikken Sekkei, 2010.

8. "The pools can merge with each other, creating new hybrid landscapes, and are designed to passively separate water and salt, generating a regional water (and salt) economy". AMOROSO, Nadia. 'Lateral Offices: Water Economies / Ecologies, Imperial Valley', en: Digital Landscape Architecture Now. Londres: Thames and Hudson, Ltd, 2012. pp. 150-155.

9. El avance más obvio -cambio de plantas y secciones hacia un homogéneo espacio virtual en 3D- obscurece la propuesta más radical referente a un sistema paramétrico multimodal con varias ventanas de información. DAVIS, Daniel; PETERS, Brady. 'Design Ecosystems: Customising the Architectural Design Environment with Software Plugs-in', en: 'Computation Works: The Building of Algorithmic Thought', AD. Architectural Design. Marzo 2013.
NOTES

1. RAHM, Philippe. 'Form and Function Follow Climate', in: CLÉMENT, Gilles; RAHM, Philippe. Environ (ne) ment. Milan: Canadian Centre for Architecture, Skira Editions, 2006. pp. 152-159.

2. ISHIGAMI, Junya. 'Rain', in: Another Scale of Architecture. Tokyo: Seigensha Art Publising, 2010. pp. 183-212.

3. Most of the definition of aereal, aquatic, electric and optical wheater events belong to this encyclopedia that analyses these atmospheric phenomena through the energy exchange between fluids. It is important to mention the great amount of information about them. Diccionario

Enciclopédico Hispano-americano de Literatura, Ciencias, Artes, etc. W.M. Jackson (ed.). London: Waterloo Place 14, late 19th Century.

4. ALLEN, Stan. 'Infrastructural Urbanism', in: Points and lines: Diagrams and Projects for the City. New York: Princeton Architectural Press, 1999. pp. 46-57.

5. CORNER, James. 'Terra Fluxus', in: WALDHEIM, Charles (ed.). The landscape Urbanism Reader. New York: Princeton Architectural Press, 2006. pp. 21-32.

6. "Expressways are like rivers. These rivers frame the area to be served. Rivers have harbors. Harbors are the municipal parking towers. From the harbors branch a system of canals that serve the interior. The canals are the go streets. From the canals branch cul-de-sac docks. The docks serve as entrance halls to the buildings". KAHN, Louis I. 'Toward a Plan for Midtown Philadelphia', en: Perspecta 2. 1953. Quoted in CORNER, James. 'Terra Fluxus'. Opus cit.

7. 'In other words, 'pull' versus 'push'; where 'pull' means the option of providing a product or a service only when it is demanded by costumers and where 'push' means the option of building a product and after selling it”. MATSUNAMA, Katashi. 'Toward the Realization of ZEBs', in: Sustainable Architecture in Japan. The Continuous Challenge 1900-2010 \& Beyond. Tokyo: Editorial Board Members of Nikken Sekkei, 2010.

8. "The pools can merge with each other, creating new hybrid landscapes, and are designed to passively separate water and salt, generating a regional water (and salt) economy". AMOROSO, Nadia. 'Lateral Offices: Water Economies / Ecologies, Imperial Valley', en: Digital Landscape Architecture Now. London: Thames and Hudson, Ltd, 2012. pp. 150-155.

9. "The most obvious progress -the change of plans and sections to an homogeneous vitual space 3D- darkens the most radical multimodal parametric system with multiple windows to present information". DAVIS, Daniel; PETERS Brady. 'Design Ecosystems: Customising the Architectural Design Environment with Software Plugs-in', en: 'Computation Works: The Building of Algorithmic Thought', AD. Architectural Design. March 2013. 


\section{REFERENCIAS}

ALLEN, Stan: 'Infrastructural Urbanism', en: Points and Lines: Diagrams and Projects for the City. Nueva York: Princeton Architectural Press, 1999. pp. 46-57.

AMOROSO, Nadia. Digital Landscape Architecture Now. Londres: Thames and Hudson, Ltd, 2012.

CORNER, James. 'Terra Fluxus', en: WALDHEIM, Charles (ed.). The Landscape Urbanism Reader. Nueva York: Princeton Architectural Press, 2006. pp. 21-32.

DAVIS, Daniel; PETERS, Brady. 'Design Ecosystems: Customising the Architectural Design Environment with Software Plugs-in', en: 'Con thation Works: The Building of Algorithmic Thought', AD. Anolitectural Design. Marzo 2013.

JACKSON, W.M. (ed.). Diccionario Enciclopédico Hispano-americano de Literatura, Ciencias, Artes, etc. Londres: 14 Waterloo Place, finales del s. XIX.

ISHIGAMI, Junya. 'Rain', en: Another Scale of Architecture. Tokio: Seigensha Art Publising, 2010. pp. 183-212.

KAHN, Louis I. 'Toward a Plan for Midtown Philadelphia', en: Perspecta 2. 1953. Citado en CORNER, James. 'Terra Fluxus'. ORus cit.MATSUNAMA, Katashi. 'Toward the realization of ZEBs, en: Sustainable Architecture in Japan. The Continuous Challenge 1900-2010 \& B cyond. Tokio: Editorial Board Members of Nikken Sekkei 2010.RAHM, Philippe. 'Form and Function Follow Climate', en: CLÉMENT, Gilles; RAHM, Philippe. Environ (ne) ment. Milan: Canadian Centre for Architecture, Skira Editions, 2006. pp. 152-159.

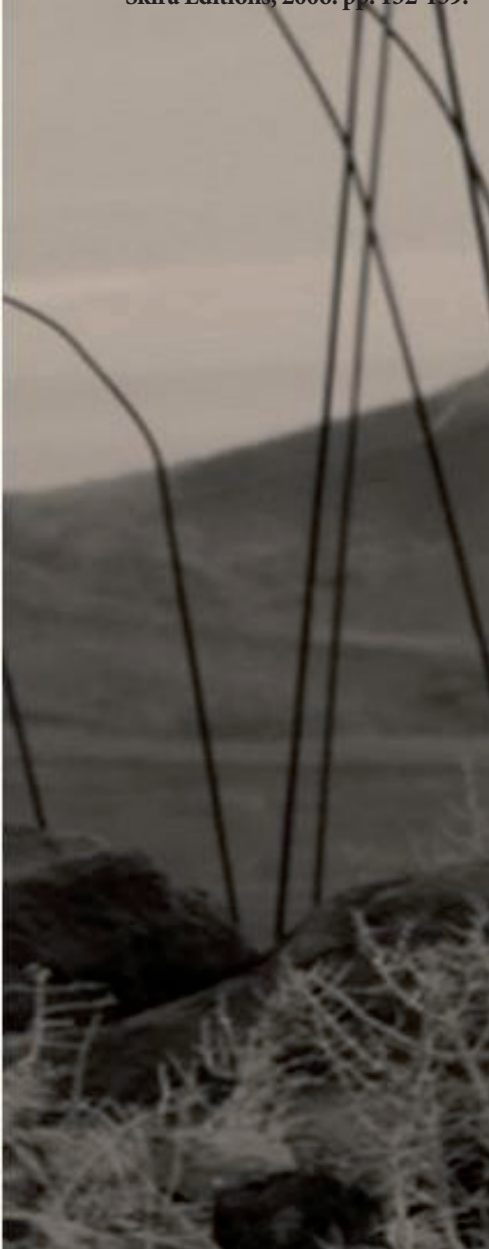

Digram and Projects for the City. New York: Princeton Architectural Press, 1999. pp. 46-57.

AMOROSO, Nadia. Digital Landscape Architecture Now. London: Thames andyudson, Ltd, 2012.

CORNER, James. 'TAya Fluxus', in: WALDHEIM, Charles (et.). The Lalfdscape Urbanishy reader. New York: Princeton Architectural Priss, 2006. pp. 21-3

DAVIS, D nniel; PETERS, Braty 'Design Ecosystems: Custo-

mising the Architectural DesignEnvironment with Software

Plags- n', en 'Computation Works: Whe Building of Algorithmic Thought', AD Architectural Design. Murzo 2013.

JACKSON, W.M. (ed.). Diccionario Endylopédico Hispano-americano de Litera ura, Ciencias, Artes, et f fondon: 1t Waterloo Place, late 19th Ontury.

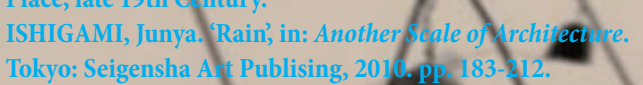

KAHN, Louis I. 'Tow rd a Plan for Midtown Philgdelphia,' n:

Perspecta 2. 1953. Qu tred in CORJVER, James. 'TE ra Fluxus.

Opus cit.

MATSUNAMA, Katashi. 'Towa A the rellization of 'EBs', in:

Sustainable Architecture fo Japin. The Colfinuous Challenge Nikken Sekkei, 2010.

RAFM, Philippe. 'Form an CLEMENT, Giligs; RAHM, nadian Centre

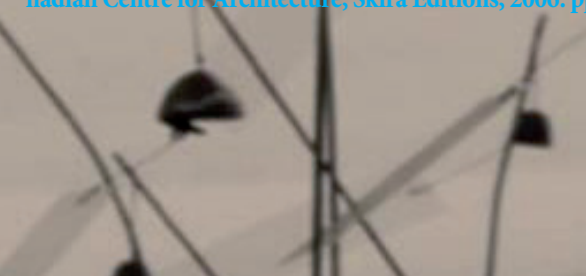

